\title{
Reading Urban Environment by Photo: A Critical Tool for Socio-Cultural Analyzing
}

\author{
Ali Asadpour \\ Department of Architecture and Environmental Design, Iran University of Science and Technology (IUST), \\ Tehran, Iran
}

\begin{tabular}{|c|c|}
\hline Abstract & Article Information \\
\hline $\begin{array}{l}\text { Photography has been used as a research tool throughout a range of disciplines. In the } \\
\text { last decades usage of photos in landscape and urban design grow noticeably; yet } \\
\text { applying it in architectural research or education for discovering social determinations } \\
\text { needs more attentions. In this study } 34 \text { participations in second year of architecture } \\
\text { were involved in a photo-survey using self snapshot photography approach for the } \\
\text { selected urban environment with open ended questionnaires in Shiraz, Iran. Despite } \\
\text { the observers' lacks of visual research skills, they pay an equal attention to physical } \\
\text { and social environment even in the absence of social activity facts in the photos. I } \\
\text { argued that students used their mental image and memories of the urban space in } \\
\text { commentaries about each photos. Besides, they used visual facts in each photo for } \\
\text { arguing and make conclusions logically. Yet, two kinds of challenges indentified in this } \\
\text { study. The first emerged from 'educational constraints' which has less attention to } \\
\text { urban spaces, social and behavioral activities in architecture education and conduce to } \\
\text { fewer comments' of observers on visual irregularities and diffusions in managing } \\
\text { signboards, urban graffiti and façade designs. The second which could be named as } \\
\text { 'cultural constraints', derives from cultural legacies and historical attachments which } \\
\text { leads observers to be more sensitive to rehabilitation and revitalization rather than new } \\
\text { buildings. Hence, the observer approaches like this, eliminated more contemporary } \\
\text { interactions between citizens and modern build environment in visual survey. }\end{array}$ & $\begin{array}{l}\text { Article History: } \\
\text { Received : 10-08-2013 } \\
\text { Revised : 24-09-2013 } \\
\text { Accepted : 25-09-2013 } \\
\text { Keywords: } \\
\text { Urban Space } \\
\text { Photo } \\
\text { Snapshot } \\
\text { Social Environment } \\
\text { Visual survey } \\
{ }^{\star} \text { Corresponding Author: } \\
\text { Ali Asadpour } \\
\text { E-mail: } \\
\text { asadpour@iust.ac.ir } \\
\end{array}$ \\
\hline
\end{tabular}

\section{INTRODUCTION}

Photography has been used as a research tool throughout a range of disciplines such as anthropology (Harper, 2002; Hoffman, 2007; Ruby, 2005), psychology, sociology and human, cultural and urban geography (Lukinbeal, 2005), cultural memory (Kuhn, 2007), education (Rich \& Chalfen, 1999) and at a range of scales to engage diverse individuals and communities (Hoffman, 2007; Moore et al., 2008). The potential for photographs to stimulate discursive reflection is known and increasingly utilized in the social science. It is axiomatic that pictures reflect wider social settings where they are produced (Caufield, 1997). In this case a photo can be a rich and useful document containing built, natural and social environment with their complicated interrelations. As a result a photo can be considered as a social construct; it obtains meaning like all other cultural objects from its context, and this can be abstracted and read (Moore et al., 2008). Therefore, visual research is concerned with the production, organization and interpretation of imagery (Prosser, 2007).

So many visual researches have been done in the case of built environment. Traditionally, William H. Whyte (1980) used time-laps filming to understand the behavior of ordinary people on city streets and plazas in New York City (Whyte, 1980) or Lynch (1960) applied interviewers' drawings to assess citizens' images of the three cities in US (Lynch, 1960). Despite urban planners, many other professions engaged in built environment and many researches have been done according to their disciplines. For instance, architectural and built environment discourses in an educational context has been studied by Fram and Margolis (2011) by 


\section{Ali Asadpour}

examining images of exterior and interior school architecture and built environments in the Gottscho and Schleisner photography collection at the Library of Congress (Fram \& Margolis, 2011). They used photographs to reflect the possessions and lifestyles of the upper-middle classes in flattering representation. Temelová and Novák (2011) studied the users of urban public space and the nature of ordinary daily street life in Prague's inner city by concerning the everyday manifestation of increasing social, lifestyle and cultural diversity using visual survey (Temelová \& Novák, 2011). Tok et al. (2010) used photography as a tool for assessing social aspects of the built environment in turkey to address architectural education. They suggested that photography can be used more fully in the context of architecture education through an interpretive process of 'reading' images (Tok, Kaplan and Taneli, 2010).

In the last decade usage of photos in landscape and urban design grow noticeably; yet applying it in architectural research or education for discovering social determinations of the design agenda or cityscape management needs more attentions. However, in more traditionally visually oriented fields, including architecture, photography is used primarily as a literal form of documentary illustration of material aspects of the built environment, rather than as a stimulus for critical interpretation or analysis of underlying social issues (Tok et al., 2010). But photography has great potential, as a method for students to represent their understandings of the built environment. This paper used photography in urban context to represent a critical interpretation by undergraduate student of architecture in Shiraz, Iran. In this research 'reading' is considered as a process of interpretation with regards to complexity and multilayer meanings including social, behavioral and cultural. As Harper (2002) argues 'reading' refer to process of elicitation which has played a greater role in recent developments in visual sociology (Harper, 2002). Despite some worldwide researches, no research has been done in this field with Iranian architecture students and fewer attempts have been conducted to use social aspects of built environment in the process of design education in Iran. I suggested that photography is a best and easiest tool for undergraduate architects to explore urban environment and can improve students' social and behavioral attentions, but it contains some challenges that regards to cultural and educational constraints.

\section{MATERIALS AND METHODS}

\section{Study Area}

In this study, 34 participations in second year of architecture at Apadana Institute of higher education
Sci. Technol. Arts Res. J., July-Sep 2013, 2(3): 153-159

institute in Shiraz, Iran were involved. Students worked individually using digital photography to consider the built environment. The study area limited to one of the most crowded and historical districts of Shiraz. The area consists of historical, modern and contemporary fabrics shown in Figure 1 and located near the center of the city. Because of many interventions during the last 100 years in this area, various architectural materials, façade designs, functions and commercial spaces are mixed together. And because of its location, most of users belong to middle or lower class of the society or are people that came from other small cities and villages near Shiraz, whom traditionally used to travel to the city for recreational- commercial activities. The area consists of some historical buildings remains from Zand dynasty (1750-1794), some newer constructions belong to Pahlavi era (1925-1979) and contemporary buildings and interventions. Mosques, shrine, school, library, garden, Shiraz main court and municipality are some of the famous buildings which surrounded the study area. Many retails and shops exist in the site which originally belongs to more than four decades ago.

The participations were asked to use 'snapshot' approach to photography in order to record direct responses of their engagement with the study area without spending too much time on composition and aesthetic aspects of photos. This approach also makes it possible to represent citizens' natural behavior that might be changed as the camera seen in front of them and also brings some unwanted or unseen objects of urbanscape to the scene that would be useful for further interpretations.

All participants shared a familiarity of the area; however, it was important that the photographs were taken during a single day without knowledge of each others' works. Basic guidelines for 'reading' the built environment were discussed in class prior to this activity; however, the concept of 'reading' photographs was introduced later, prior to the interpretation activity. The research includes 5 steps mentioned bellow:

- Taking series of photos from the study area and selecting two of them by participations for presenting to class;

- Reviewing selected photos and excluding ones with similar subjects and scene by researcher;

- Selecting two photos by random and preparing a form with a series of open ended questions by researcher;

- Completing the forms individually by participations;

- Analising the results by researcher. 


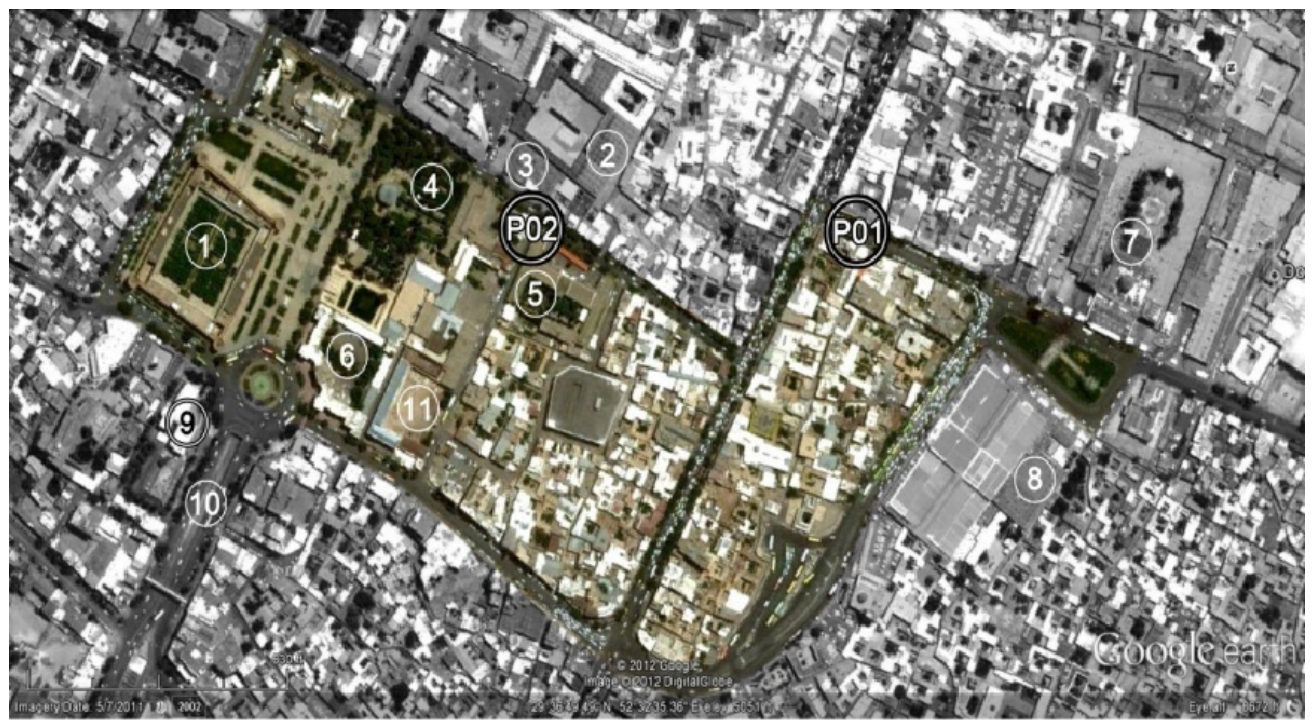

1-Arg (Castle) 2-Vakil Mosque 3- Vakil Bath 4- Nazar Garden 5- Dastgheyb Library 6-Shiraz Court

7-Shah-e-Cheragh Shrine 8-Noe Mosque 9-Shiraz Municipality 10-Zand Street 11-Namazi School

Figure 1: Study Area.

The open ended questions consist of three parts: i) 'Read' this photo and tell us about it; ii) keywording the photo respectively with five words and iii) Why do you think the photographer chose this photo to present among the other photos? The first question is based on the term 'reading a photo' and asked the student to write a paragraph about their interpretations for each photo. The second one is about keywording which is a selective process not unrelated to the process of choosing particular images to share and discuss. In this sense keywording is an akin to a process of framing which has value in narrowing down the number of available features in the photo (Tok et al., 2010). The final question asked the students the photographers' points of views for selecting the photo. This question makes it possible to compare as if the shared familiarity of the study area lead to the same interpretations among photographer and observers.

\section{RESULTS AND DISCUSSIONS}

Body of photos has been prepared by this method (Figure 2), but as mentioned above each student could only bring two photos to the class. As a result, 34 images collected in which 3 photos have similar subject with the similar scene. Hence, 2 of these photos excluded from the rest of research by random. Undergraduate students of architecture which engaged in this study have very little knowledge about visual research, nevertheless the interpretations not only address the physical forms and materials of the urban fabric but also shown the social-behavioral factors that sometimes combined to physical settings with multilayered meanings.
In the following discussion the two picked out photographs of a total 32 one are displayed. The first photo (P-01, Figure 3 ) shows an old semidemolished public bath and some retail shops with pedestrian flows in front of them, whereas the second one (P-02, Figure 5) represent an old wooden façade with closed shops and urban signs without any social activities. A corresponding table, which includes the 5 random participant observers' (out of a total of 34 participant observers) interpretation and keywording, follow each photo. Figure 4 and 6 represent categorized open ended questionnaires' responds based on their initial character for each photo. Responds to all three questions are summarized to 11 categories named Erosion and Deterioration, Contradiction, People and Daily Life, Traffic and Crowd, Urban and Building Functions, Signs Irregularity, Materials, Ugliness and Dirtiness, Historical Fabric, Culture and Tradition and others. It is notable that $35 \%$ of observer mentioned 3 and less keywords and only $30 \%$ of them noticed 5 keywords for the second question.

Through their photographs and commentary, the students have considered the complexity of the site with multiple dimensions and possible interpretations (Table 1). For instance, by exploiting visual facts presented in the photo P-01, the observer 3 argued from the gable roof of the bath building that Shiraz weather conditions have been changed during the last decades.

Although usage of this kind of roof is more about structural needs rather than heavy rainfalls but the processes of concluding from facts in the scene to climate changes is worthwhile. 


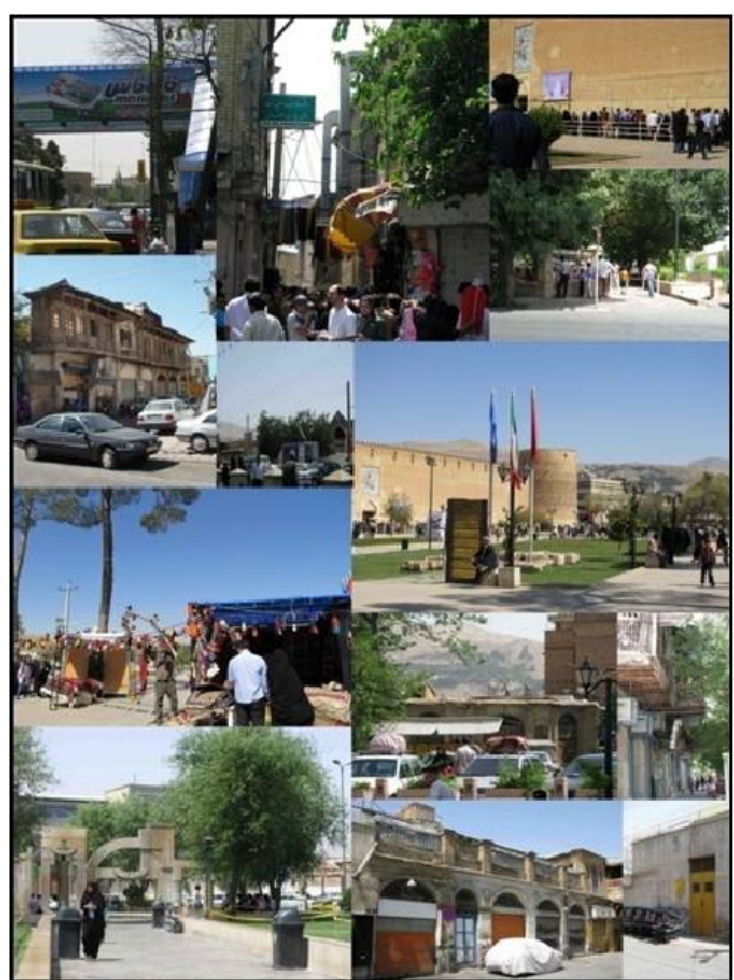

Figure 2: Sample of photos taken from study area by participants.

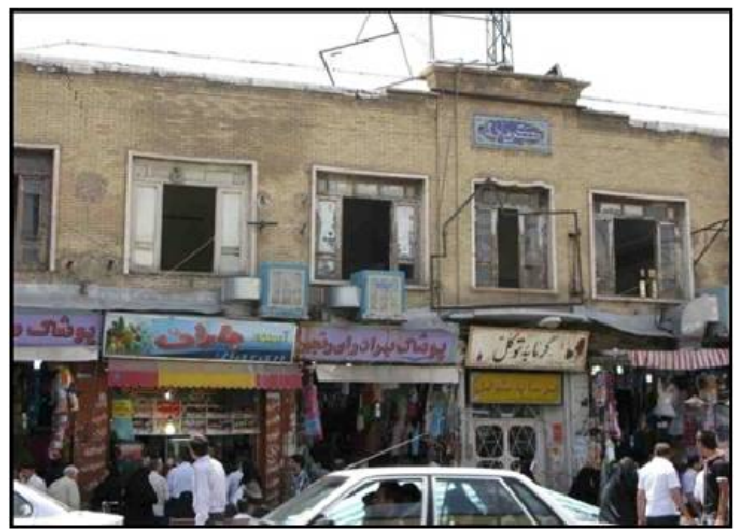

Figure 4: Categorizing open ended questionnaires respond based on its initial character for photo P-01.

According to Figure 4, most attention has been paid to urban and buildings functions such as retails, shops, public bath and their juxtapositions. People, human activity, social and daily life especially in keywording have been mentioned noticeably in interpreters responds. Besides, the students engaged in this survey imply that these items are the notable reasons of presenting photo01 to the class by photographer. In general

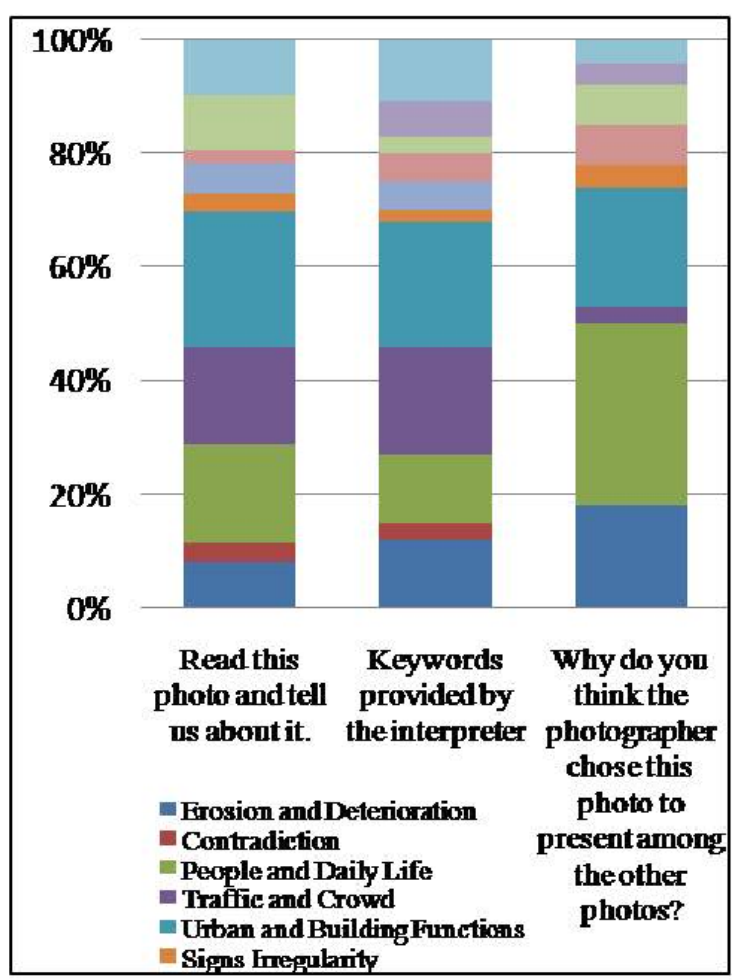

Figure 3: Photo P-01 taken from study area by one of the participants.

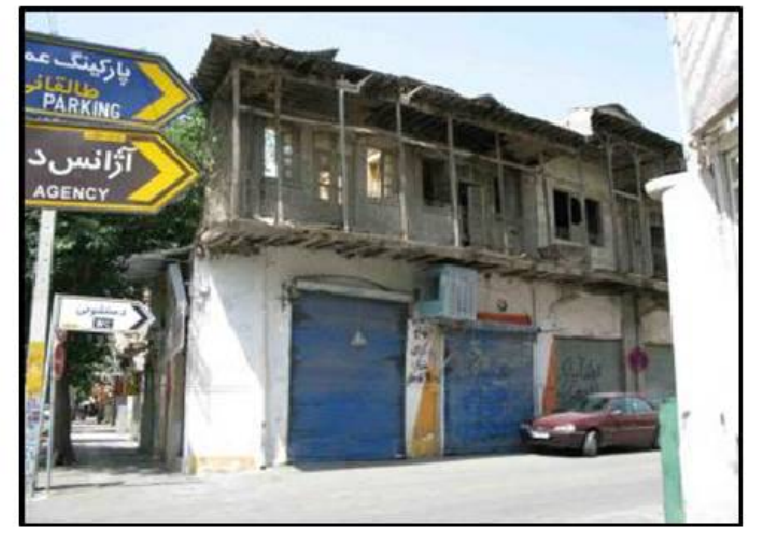

Figure 5: Photo P-02 taken from study area by one of the participants.

buildings and urban fabric erosion and deterioration were adverted in almost all of responds; however mentioning pedestrians, traffic and crowding is the second most mentioned item by students as respond to reading and commenting the photo P-01. Less attention was paid to signs, fascia or signboards irregularities which conduced to diffusion cityscape, its dirtiness and chaos of visual quality. 
Ali Asadpour

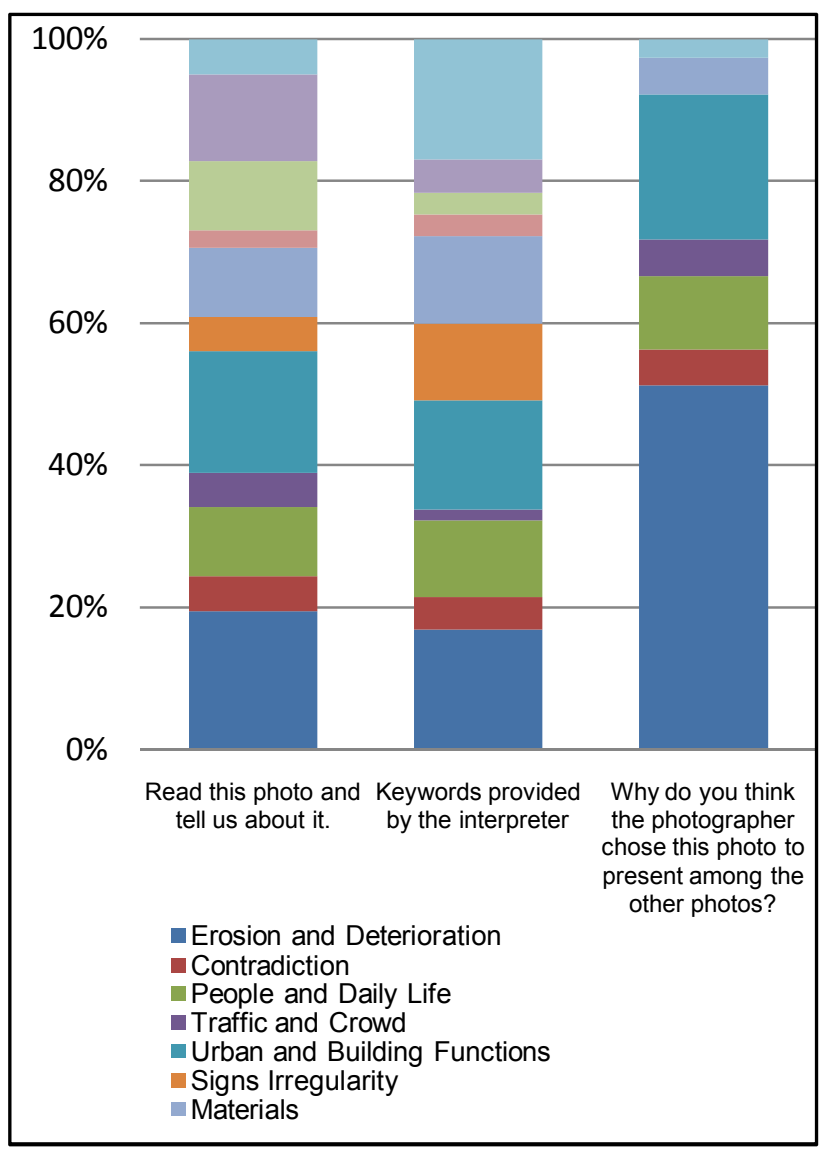

Figure 6: Categorizing open ended questionnaires respond based on its initial character for photo P-02.

The story of the second photo (P-02) is a little different. General characteristics of these two photos are resembled to each other; an old halfdestroyed building with shops in ground level. The only differences of these two photos refer to lack of human activities such as social interactions and pedestrian flows which are absent in P-02. But interpreters comments, particularly in observer 2 (Table 2), is an example of concluding from citizens behavioral facts the presence of human activities. According to observer 2, despite the graffiti and no parking sign, parking a car in front of a closed shop was consequentiality of an intentioned person. Referring to childhood memories or citizens life stories in the past, represent tangible parts of an image that observer 12, for instance discovered from the scene. Nevertheless, emphasising on oldfashioned edifices that are going to demolish, its erosion and conditions or composition of traffic signs, mentioned in almost all of responds by student for photo P-02.

In general absence of people in this photo not only changed the observers' points of views in interpreting the scene, but also leads to more complicated conclusions which are based on facts
Sci. Technol. Arts Res. J., July-Sep 2013, 2(3): 153-159

emerged from human interactions in environment and their behavioral settings. By concluding from a parking lot sign in the left side of the photo, one observer find out that the traffic and crowding in the surroundings would be high during a day.

Likewise the photo P-01, majority of comments for the second photo belongs to describing functions of the buildings in the scene, erosion of an old halfdestroyed building and people and everyday life represented in the photo. Here, attention to signboards and usage of materials are more noticeable than photo P-01, but their effect on cityscape and visual qualities are neglected in the comments. Students' comments on the photos when asked to 'read' the images and keywording them, are different to their points of views about photographer intentions to select that photo.

In the first photo, where a social activity is more visible, people and daily life of citizens allocated the great number of responds, while in the second photo where the built environment is dominant, most of comments belong to erosion of an old building. These comments are exactly different to students' responds for reading and keywording the photos. On the other hand, by comparing observers' points of views with their guess about photographer intentions, we can conclude that, students have a moderate analysis and interpretations by providing equal attention to physical and social parameters in the photos at the same time which may not exactly coincide with conventional photographer aims. More important is their awareness about these differences in commentaries.

\section{CONCLUSION}

Photography has been used as a research tool throughout a range of disciplines. In this research students of the second year of architecture were engaged in a photo-survey using self snapshot photography approach for the selected urban environment in Shiraz, Iran and completed open ended questionnaires. Observers' interpretations and comments' of students represent the moderate manners towards two different types of photos; first with absence and second with presence of social activities. In another word, despite the observers' lacks of visual research skills, they pay an equal attention to physical and social environment by presuming the build environment as a container of human activities. I argued that students used their mental image and memories of the urban space in commentaries about each photos. Besides, they used visual facts of each photo for arguments and conclusions in a logical way. The fact that students make notification about citizens' daily and ordinary lives in the city, even in the absence of pedestrian flows or social interactions in the scene are worthwhile. 
Table1: Interpretations of Photo P-01 by five random observer participants.

\begin{tabular}{|c|c|c|c|}
\hline Interpreter & $\begin{array}{l}\text { Written interpretations provided as a } \\
\text { response to the question: 'Read this } \\
\text { photo and tell us about it'. }\end{array}$ & $\begin{array}{l}\text { Keywords provided } \\
\text { by the interpreter in } \\
\text { order of importance. }\end{array}$ & $\begin{array}{l}\text { Answers provided as a } \\
\text { response to the question: } \\
\text { 'Why do you think the } \\
\text { photographer chose this } \\
\text { photo to present among } \\
\text { the other photos?' }\end{array}$ \\
\hline Observer 3 & $\begin{array}{l}\text { The bath building shows the history of } \\
\text { the street, windows and gable roof do } \\
\text { the same. The gable roof represents } \\
\text { the climate conditions and changes in } \\
\text { shiraz that gets more arid as the time } \\
\text { passed. A high traffic street with } \\
\text { vehicles and shops contradictory. }\end{array}$ & $\begin{array}{l}\text { Antiquity, } \\
\text { Contradiction, Time } \\
\text { passing }\end{array}$ & $\begin{array}{l}\text { We live with history and also } \\
\text { go far from it. }\end{array}$ \\
\hline Observer 4 & People live stream, Profile of the city & $\begin{array}{lr}\text { People, } & \text { Buildings, } \\
\text { Movement } & \text { And } \\
\text { Traffics, Life, } & \text { Antiquity }\end{array}$ & $\begin{array}{l}\text { He/she wants to representing } \\
\text { a lifestyle, people and in } \\
\text { general a particular fabric of } \\
\text { the city. }\end{array}$ \\
\hline Observer 6 & $\begin{array}{l}\text { Chaos, Traffic, Confusion of shops, } \\
\text { Presence of a bath building in the } \\
\text { middle of this irregularity. }\end{array}$ & $\begin{array}{l}\text { Tavakol Bath, Traffic, } \\
\text { Irregularity, shop Signs }\end{array}$ & $\begin{array}{l}\text { Wanted to show irregularity } \\
\text { and the worst composition of } \\
\text { shops. }\end{array}$ \\
\hline Observer 10 & $\begin{array}{l}\text { An old bazaar with any functions } \\
\text { composition without any relationships. } \\
\text { Spaces for public daily needs with } \\
\text { people friendly conditions. }\end{array}$ & $\begin{array}{l}\text { Traffic, History, Daily } \\
\text { Life of Ordinary } \\
\text { People, Dirtiness, } \\
\text { Small Bazaar }\end{array}$ & $\begin{array}{l}\text { To representing the city } \\
\text { profile. }\end{array}$ \\
\hline Observer 17 & $\begin{array}{l}\text { Despite the shops in the ground floor } \\
\text { the second floor is out of resident. }\end{array}$ & $\begin{array}{lr}\text { Traffic, } & \text { Variety of } \\
\text { Shops, } & \text { Multiple } \\
\text { Functions Together, } \\
\text { Overpopulation and } \\
\text { Cars, Half Old }\end{array}$ & $\begin{array}{l}\text { He/she wants to show the } \\
\text { empty floor is occupied with } \\
\text { crowd! }\end{array}$ \\
\hline
\end{tabular}

Table 2: Interpretation of Photo P-02 by five random observer participants.

\begin{tabular}{|c|c|c|c|}
\hline Interpreter & $\begin{array}{l}\text { Written interpretations provided as a } \\
\text { response to the question: 'Read this } \\
\text { photo and tell us about it'. }\end{array}$ & $\begin{array}{l}\text { Keywords provided by } \\
\text { the interpreter in order } \\
\text { of importance. }\end{array}$ & $\begin{array}{l}\text { Answers provided as a } \\
\text { response to the question: } \\
\text { 'Why do you think the } \\
\text { photographer chose this } \\
\text { photo to present among the } \\
\text { other photos?' }\end{array}$ \\
\hline Observer 2 & $\begin{array}{l}\text { The building stands like a crust and it's } \\
\text { not legible. People don't attention to } \\
\text { traffic signs (Don't stop). Besides, the } \\
\text { cooler has no cannel! }\end{array}$ & $\begin{array}{l}\text { Public attentions, } \\
\text { Attention to Surroundings, } \\
\text { Public Fault }\end{array}$ & $\begin{array}{l}\text { He/ she might have wanted to } \\
\text { show peoples' every day } \\
\text { mistakes. }\end{array}$ \\
\hline Observer 5 & $\begin{array}{l}\text { An old architecture that has newer } \\
\text { adjoining. Transforming an old district to } \\
\text { parking lot. }\end{array}$ & Old, Dating and Erosion & $\begin{array}{l}\text { Familiarization with historic } \\
\text { district and paying no attention } \\
\text { to it. }\end{array}$ \\
\hline Observer 6 & $\begin{array}{l}\text { Deterioration and erosion of an old } \\
\text { fabric of the city with irregular and not } \\
\text { harmonized traffic signs according to its } \\
\text { dimensions and proportions, Dirty and } \\
\text { cramped wall. }\end{array}$ & $\begin{array}{l}\text { Demolished Old Building, } \\
\text { Inappropriate Urban } \\
\text { Elements, Traffic Signs }\end{array}$ & $\begin{array}{l}\text { He/she wants to represent an } \\
\text { inappropriate use of old } \\
\text { buildings in the district. }\end{array}$ \\
\hline Observer 12 & $\begin{array}{l}\text { There is may be a contradiction in this } \\
\text { scene; remembering pasted days that } \\
\text { only its ruins remains, Memory of our } \\
\text { childhood and people who were some } \\
\text { day alive or are aged know. }\end{array}$ & $\begin{array}{l}\text { Old and New, Cultural } \\
\text { Differences, Inattention to } \\
\text { Law, Lack of Amenity in } \\
\text { all Parts of The City. }\end{array}$ & $\begin{array}{l}\text { May be he/she desired to } \\
\text { represent that modernism is as } \\
\text { beautiful as its ugliness. Here it } \\
\text { changes the existing form that } \\
\text { is not suitable for this condition. }\end{array}$ \\
\hline Observer 17 & $\begin{array}{l}\text { By looking to this scene I have a sense } \\
\text { of antiquity. Buildings that were onetime } \\
\text { interesting places but now... }\end{array}$ & $\begin{array}{lrr}\text { Upper level, } & \text { Erosion, } \\
\text { Shiraz Old } & \text { Fabric, } \\
\text { Wooden, Firm } & \end{array}$ & $\begin{array}{l}\text { Wants to look at the old building } \\
\text { in shiraz, shows their nowadays } \\
\text { conditions. }\end{array}$ \\
\hline
\end{tabular}




\section{Ali Asadpour}

Yet, two kinds of challenges indentified in this study. The first emerged from 'educational constraints' which has less attention to urban spaces, social and behavioral activities in under graduate architecture education. For instance, despite visual irregularities and diffusions in managing signboards, urban graffiti and façade designs which are ordinary in most cityscape of Shiraz, fewer attentions could be seen in commentaries by the students. Furthermore, the entity of the comments in this field is more general than specific. The second challenge that could be named as 'cultural constraints', derives from cultural legacy concerns and historical attachments. Shiraz like any parts of Iran has an old history and is located near Persepolis from Achaemenian era, Sassanid emperor ruins and has significant edifices and gardens remain from Islamic periods.

Although some modern buildings and well maintenance historical ones stands in the study area but only 2 photos out of a total of 34 photos represent them. Culturally, architecture students engaged in this research seems to be more sensitive to rehabilitation and revitalization rather than new buildings. Hence, the observer approaches like this eliminated more contemporary interactions between citizens and modern build environment in current survey. Further comparative studies should be done with other parts of the world to examine the accuracy of the two mentioned constraints which regards to students' analysis limitation. But in general, historicity believes or attention to cultural identity could not be ignored in many social classes of Iranian citizens.

\section{REFERENCES}

Caufield, J. (1997). The production of pictures: An institutional approach. Visual Sociology 12(1): 59-71.

Fram, S. and Margolis, E. (2011). Architectural and built environment discourses in an educational context: the Gottscho and Schleisner Collection. Visual Studies 26(3): 229-243.
Sci. Technol. Arts Res. J., July-Sep 2013, 2(3): 153-159

H.Whyte, W. (1980). The social life of small urban spaces: The conservation foundation press, Washington D.C.

Harper, D. (2002). Talking about pictures: A case for photo elicitation. Visual Studies 17(1): 13-26.

Hoffman, D. (2007). The Disappeared: images of the environment at Freetown's urban margins. Visual Studies 22(2): 104-119.

Kuhn, A. (2007). Photography and cultural memory: a methodological exploration. Visual Studies 22(3): 283-292.

Lukinbeal, C. (2005). Cinematic Landscapes. Journal of Cultural Geography 23(1): 3-22.

Lynch, K. (1960). The Image of The City: Publication of The Joint Center for Urban Studies.

Moore, G., Croxford, B., Adams, M., Refaee, M., Cox, T., \& Sharples, S. (2008). The photo-survey research method: capturing life in the city. Visual Studies 23(1): 50-62.

Prosser, J. (2007). Visual methods and the visual culture of schools. Visual Studies 22(1): 13-30.

Rich, M., \& Chalfen, R. (1999). Showing and telling asthma: Children teaching physicians with visual narrative. Visual Sociology, 14(1): 51-71.

Ruby, J. (2005). The last 20 years of visual anthropology - a critical review. Visual Studies 20(2): 159-170.

Temelová, J., \& Novák, J. (2011). Daily street life in the inner city of Prague under transformation: the visual experience of socio-spatial differentiation and temporal rhythms. Visual Studies 26(3): 213228. doi:

Tok, S. Y., Kaplan, I., and Taneli, Y. (2010). Photography in architectural education: A tool for assessing social aspects of the built environment. Procedia - Social and Behavioral Sciences 2(2): 2583-2588. 